\title{
Observed decline of the Atlantic meridional overturning circulation 2004-2012
}

\author{
D. A. Smeed ${ }^{1}$, G. D. McCarthy ${ }^{1}$, S. A. Cunningham ${ }^{2}$, E. Frajka-Williams ${ }^{3}$, D. Rayner ${ }^{1}$, W. E. Johns ${ }^{4}$, C. S. Meinen ${ }^{5}$, \\ M. O. Baringer ${ }^{5}$, B. I. Moat ${ }^{1}$, A. Duchez ${ }^{1}$, and H. L. Bryden ${ }^{3}$ \\ ${ }^{1}$ National Oceanography Centre, European Way, Southampton, SO14 3ZH, UK \\ ${ }^{2}$ Scottish Association for Marine Science, Scottish Marine Institute Oban, Argyll, PA37 1QA, UK \\ ${ }^{3}$ National Oceanography Centre, University of Southampton, Waterfront Campus, Southampton SO14 3ZH, UK \\ ${ }^{4}$ University of Miami, Rosenstiel School of Marine and Atmospheric Science, 4600 Rickenbacker Causeway, Miami, \\ FL, USA \\ ${ }^{5}$ Atlantic Oceanographic and Meteorological Laboratory, Miami, FL, USA
}

Correspondence to: D. A. Smeed (das@noc.ac.uk)

Received: 15 August 2013 - Published in Ocean Sci. Discuss.: 13 September 2013

Revised: 6 December 2013 - Accepted: 9 December 2013 - Published: 6 February 2014

\begin{abstract}
The Atlantic meridional overturning circulation (AMOC) has been observed continuously at $26^{\circ} \mathrm{N}$ since April 2004. The AMOC and its component parts are monitored by combining a transatlantic array of moored instruments with submarine-cable-based measurements of the Gulf Stream and satellite derived Ekman transport. The time series has recently been extended to October 2012 and the results show a downward trend since 2004. From April 2008 to March 2012, the AMOC was an average of $2.7 \mathrm{~Sv}\left(1 \mathrm{~Sv}=10^{6} \mathrm{~m}^{3} \mathrm{~s}^{-1}\right)$ weaker than in the first four years of observation $(95 \%$ confidence that the reduction is $0.3 \mathrm{~Sv}$ or more). Ekman transport reduced by about $0.2 \mathrm{~Sv}$ and the Gulf Stream by $0.5 \mathrm{~Sv}$ but most of the change $(2.0 \mathrm{~Sv})$ is due to the mid-ocean geostrophic flow. The change of the mid-ocean geostrophic flow represents a strengthening of the southward flow above the thermocline. The increased southward flow of warm waters is balanced by a decrease in the southward flow of lower North Atlantic deep water below $3000 \mathrm{~m}$. The transport of lower North Atlantic deep water slowed by $7 \%$ per year $(95 \%$ confidence that the rate of slowing is greater than $2.5 \%$ per year).
\end{abstract}

\section{Introduction}

The poleward transport of heat in the sub-tropical North Atlantic has been shown (Johns et al., 2011) to be highly correlated with the Atlantic meridional overturning circulation $(\mathrm{AMOC})$. One petawatt $\left(\mathrm{PW}=10^{15} \mathrm{~W}\right)$ of heat carried by the AMOC is released to the atmosphere between $26^{\circ} \mathrm{N}$ and $50^{\circ} \mathrm{N}$ and has important impacts on the climate of the North Atlantic region (e.g. Srokoz et al., 2012). The AMOC varies on a range of timescales (e.g. Eden and Willebrand, 2001; Kanzow et al., 2010) and is thought to have played a key role in rapid climate change in the past (Ganopolski and Rahmstorf, 2001). Model simulations predict a decrease of the AMOC in the 21st century in response to increasing greenhouse gases (IPCC, 2007). Decadal-scale changes in the AMOC have been associated with the Atlantic multidecadal oscillation in climate simulations (Knight et al., 2005) and are thought to have impacts on surface temperature, precipitation and sea level in regions bordering the ocean (Delworth and Mann, 2000). The role of the AMOC in climate has motivated oceanographers to quantify its strength and variability.

The first observational estimates of the basin-wide AMOC were based on transatlantic hydrographic sections (Bryden and Hall, 1980; Roemmich and Wunsch, 1985). These observations provided important information about the structure and magnitude of the AMOC, but, with only a handful 
of these snapshots, insight into the variability was limited. To quantify the variability it was proposed in the early 2000s to establish a dedicated observing system to make continuous measurements of the variability of the AMOC at $26^{\circ} \mathrm{N}$ (Cunningham et al., 2007). Early results highlighted the seasonal and shorter scale variability and enabled the quantification of the error bars for the hydrographic snapshot measurements (Kanzow et al., 2010).

Inter-annual AMOC variability was small compared to the seasonal variation during the first $4 \mathrm{yr}$ of observations, but in 2009-2010 there was a large (30\%) downturn in the strength of the AMOC (McCarthy et al., 2012). This caused a reduction in the heat content of the subtropical North Atlantic (Cunningham et al., 2013). Cunningham et al. (2013) suggested that this reduction was the major contributor to low wintertime sea-surface temperatures in the region between $26^{\circ} \mathrm{N}$ and $41^{\circ} \mathrm{N}$. The downturn of 2009-2010 was followed by an anomalously cold winter in NW Europe with strong negative North Atlantic oscillation (NAO) in December 2010. Maidens et al. (2013) noted that the anomalous conditions were predicted by long-range forecasts several months in advance. Using an ensemble of hindcasts, Maidens et al. (2013) concluded that the factor that led to the predictability of this winter was the anomalous upper-ocean heat content and SST. This suggests that the monitoring AMOC at $26^{\circ} \mathrm{N}$ can provide valuable information for seasonal prediction.

The $26^{\circ} \mathrm{N}$ RAPID-MOCHA-WBTS program (hereafter referred to as the $26^{\circ} \mathrm{N}$ program) has thus provided important information about inter-annual, seasonal and shorter term variability of the AMOC but the limited length of the time series has precluded investigation of longer timescales. With the extension of the record to $8.5 \mathrm{yr}$ we now present the first look at multi-year trends in the AMOC at $26^{\circ} \mathrm{N}$.

\section{The calculation of the AMOC}

The principles of the calculation of the AMOC volume transport have been described elsewhere (Cunningham et al., 2007; Kanzow et al., 2007). There are three main components to the measurements (Fig. 1). Firstly, the Gulf Stream transport ( $\left.T_{\mathrm{GS}}\right)$ in the Florida Straits is measured by submarine cable measurements and quarterly hydrographic cruises (Baringer and Larsen, 2001; Meinen et al., 2010). Secondly, the Ekman transport $\left(T_{\mathrm{EK}}\right)$ is determined from atmospheric reanalyses. In the analysis presented here the ERA interim product is used (Dee et al., 2011). Thirdly, an array of moored instruments measures the flow from the Bahamas to the continental shelf off Africa. The mooring array consists of two parts. From the Bahamas to $20 \mathrm{~km}$ offshore $\left(76.75^{\circ} \mathrm{W}\right)$, current metre moorings make direct estimates of the flow (Johns et al., 2008). East of $76.75^{\circ} \mathrm{W}$, an array of dynamic height moorings carrying vertical strings of temperature-salinity-pressure sensors defines the mid-ocean

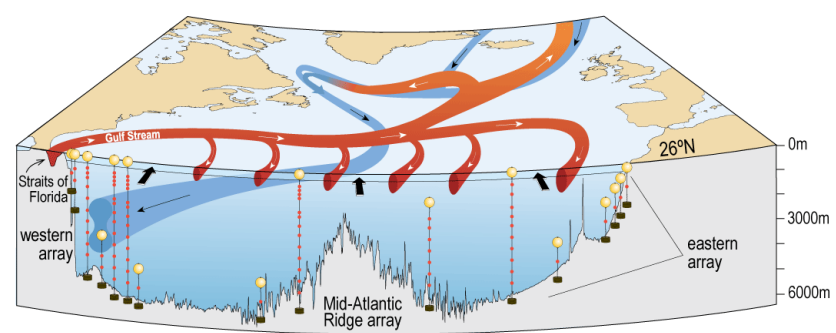

Fig. 1. Schematic diagram illustrating the component parts of the AMOC and the $26^{\circ} \mathrm{N}$ observing system. Black arrows represent the Ekman transport (predominantly northward). Red arrows illustrate the circulation of warm waters in the upper $1100 \mathrm{~m}$, and blue arrows indicate the main southward flow of colder deep waters. The array of moorings used to measure the interior geostrophic transport is illustrated too.

geostrophic flow to the eastern boundary. The combined transports from the moorings are referred to herein as the internal transport $\left(T_{\mathrm{INT}}\right)$. Geostrophic calculations require a level of known motion, which, for the AMOC calculation, is determined by applying a constraint of zero net mass transport across the section. The additional transport necessary to satisfy this constraint is referred to as the external transport $\left(T_{\text {EXT }}\right)$. While the external transport is defined to satisfy an imposed constraint, this has been independently validated using in situ bottom pressure data (Kanzow et al., 2007; McCarthy et al., 2012). The internal and external transports are combined to give a zonally integrated mid-ocean transport profile as a function of depth. Transport profiles from the Gulf Stream in the Florida Straits and from the basinwide Ekman layer are added to those from the internal and external transports to get a total transport profile.

$T(z, t)=T_{\mathrm{GS}}(z, t)+T_{\mathrm{EK}}(z, t)+T_{\mathrm{INT}}(z, t)+T_{\mathrm{EXT}}(z, t)$

Vertical integration of the transport profile results in the volume transport stream function, and the AMOC transport is defined to be the maximum of the stream function. This maximum predominantly occurs around $1100 \mathrm{~m}$. Because the Ekman and Gulf Stream transport both occur shallower than $1100 \mathrm{~m}$ (Ekman transport is assumed to be within the upper $100 \mathrm{~m}$ and the maximum depth of the Florida Straits is $760 \mathrm{~m}$ ) we can express the AMOC as the sum of three components

$\operatorname{MOC}(t)=\mathrm{GS}(t)+\mathrm{EK}(t)+\mathrm{UMO}(t)$,

where we define upper mid-ocean (UMO) transport to be the mid-ocean transport above the depth of the maximum of the basin-wide AMOC stream function. This is in effect the volume transport of the southward flowing recirculation of the subtropical gyre less the northward flowing Antilles Current (Meinen et al., 2004). 
Table 1. Annual averages of the AMOC and its components. Each annual average is for a 12 month period that starts on 1 April of the named year. Also shown are multi-year averages. All values are in Sv. Positive is northward.

\begin{tabular}{lrrrrrr}
\hline Year(s) & AMOC & Ekman & $\begin{array}{r}\text { Gulf } \\
\text { Stream }\end{array}$ & $\begin{array}{r}\text { Upper } \\
\text { mid-ocean }\end{array}$ & UNADW & LNADW \\
\hline 2004 & 17.8 & 3.2 & 31.8 & -17.1 & -11.7 & -6.9 \\
2005 & 20.1 & 3.5 & 32.0 & -15.4 & -11.9 & -8.5 \\
2006 & 19.5 & 4.0 & 31.6 & -16.1 & -11.7 & -8.1 \\
2007 & 18.0 & 3.8 & 31.6 & -17.3 & -11.3 & -7.0 \\
2008 & 17.5 & 4.0 & 32.2 & -18.6 & -11.4 & -6.7 \\
2009 & 12.9 & 2.2 & 30.7 & -20.0 & -10.6 & -3.5 \\
2010 & 16.7 & 3.0 & 31.0 & -17.2 & -12.5 & -5.2 \\
2011 & 17.5 & 4.5 & 31.1 & -18.0 & -11.6 & -6.5 \\
$2004-2007$ & 18.9 & 3.6 & 31.8 & -16.5 & -11.6 & -7.6 \\
$2008-2011$ & 16.2 & 3.4 & 31.3 & -18.5 & -11.5 & -5.5 \\
$2008,2010,2011$ & 17.2 & 3.8 & 31.4 & -18.0 & -11.8 & -6.1 \\
\hline
\end{tabular}

\section{Results}

\subsection{Time series}

In Fig. 2 we show the time series of the AMOC and its components parts: the Gulf Stream transport, the Ekman transport and the UMO transport as described in the previous section.

Kanzow et al. (2010) showed that there is a clear annual cycle in the AMOC, and therefore to identify longterm trends it is instructive to consider annual average values; these are shown in Table 1. We choose to start annual averages on 1 April. In this way we do not split the winter season; furthermore, the mid-ocean measurements began in April 2004. As highlighted by McCarthy et al. (2012), the year starting April 2009 stands out with a remarkable low in the average value of the AMOC. It is also apparent that the average value of the AMOC in each of the last $4 \mathrm{yr}$ is lower than each of the first $4 \mathrm{yr}$. If we compare the averages for the periods from April 2004 to March 2008 and from April 2008 to March 2012 then the AMOC is $2.7 \mathrm{~Sv}$ lower in the latter period. The $90 \%$ confidence interval ${ }^{1}$ (c.i.) for the distribution of possible values (Lindgren, 1993) of the reduction is 0.3 to $5.1 \mathrm{~Sv}$. Thus there is $95 \%$ confidence that the reduction in overturning is $0.3 \mathrm{~Sv}$ or more. Reduction in Ekman transport contributes $0.2 \mathrm{~Sv}$ to this decrease, and a further $0.5 \mathrm{~Sv}$ results from a small slowing of the Gulf Stream, but the major contributor is the strengthening southward flow of the UMO $(2.0 \mathrm{~Sv})$.

The year of 2009 alone contributes about $1.0 \mathrm{~Sv}$ to the difference between the two halves of the series. It could be argued that this is an extreme inter-annual event rather than a part of decade long trend so we also consider the significance of the changes without this anomalous year. Calculation of

\footnotetext{
${ }^{1}$ Note that we refer to the $90 \%$ confidence interval as the range between the 5th and 95 th percentile of the distribution of possible values. There is $95 \%$ chance that the true value is greater than the 5 th percentile of the distribution.
}

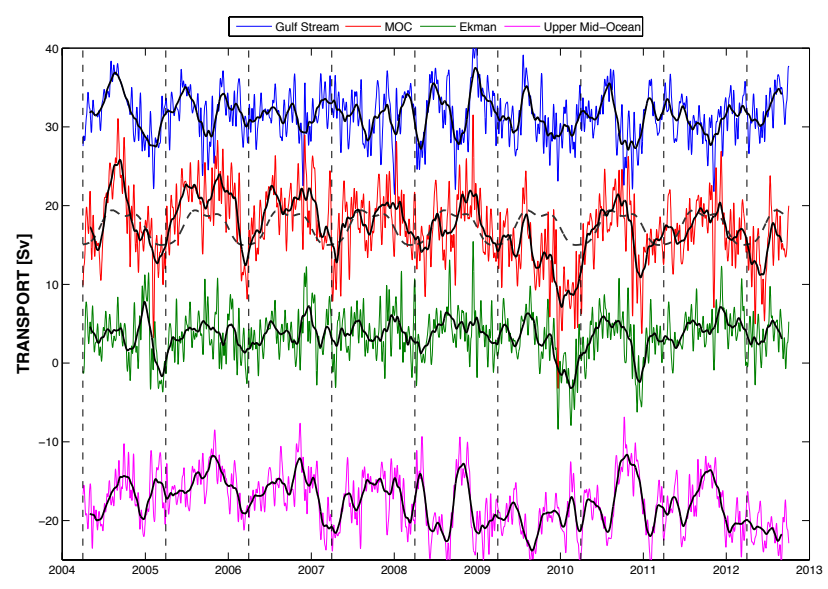

Fig. 2. Ten-day (colours) and three month low-pass (black) time series of Gulf Stream transport (blue), Ekman transport (green), upper mid-ocean transport (magenta), and overturning transport (red) for the period 1 April 2004 to 1 October 2012. A dashed black line shows the mean annual cycle for the AMOC. Positive transports correspond to northward flow.

the distribution of possible values indicates that even excluding 2009 the mean of 2008, 2010 and 2011 is lower than mean of 2004, 2005, 2006 and 2007 with $95 \%$ confidence for 5 degrees of freedom. The change in UMO has a similar level of significance but the corresponding changes in Gulf Stream and Ekman transports are not significantly different from zero. Estimated changes and confidence ranges for each of the components are summarised in Table 2.

\subsection{Anomalies relative to seasonal cycle}

An alternative approach to quantify the trend in the time series is to first remove the mean annual cycle from the data and then fit a trend by linear regression. The mean annual cycle for each component was calculated by fitting a sinusoidal 

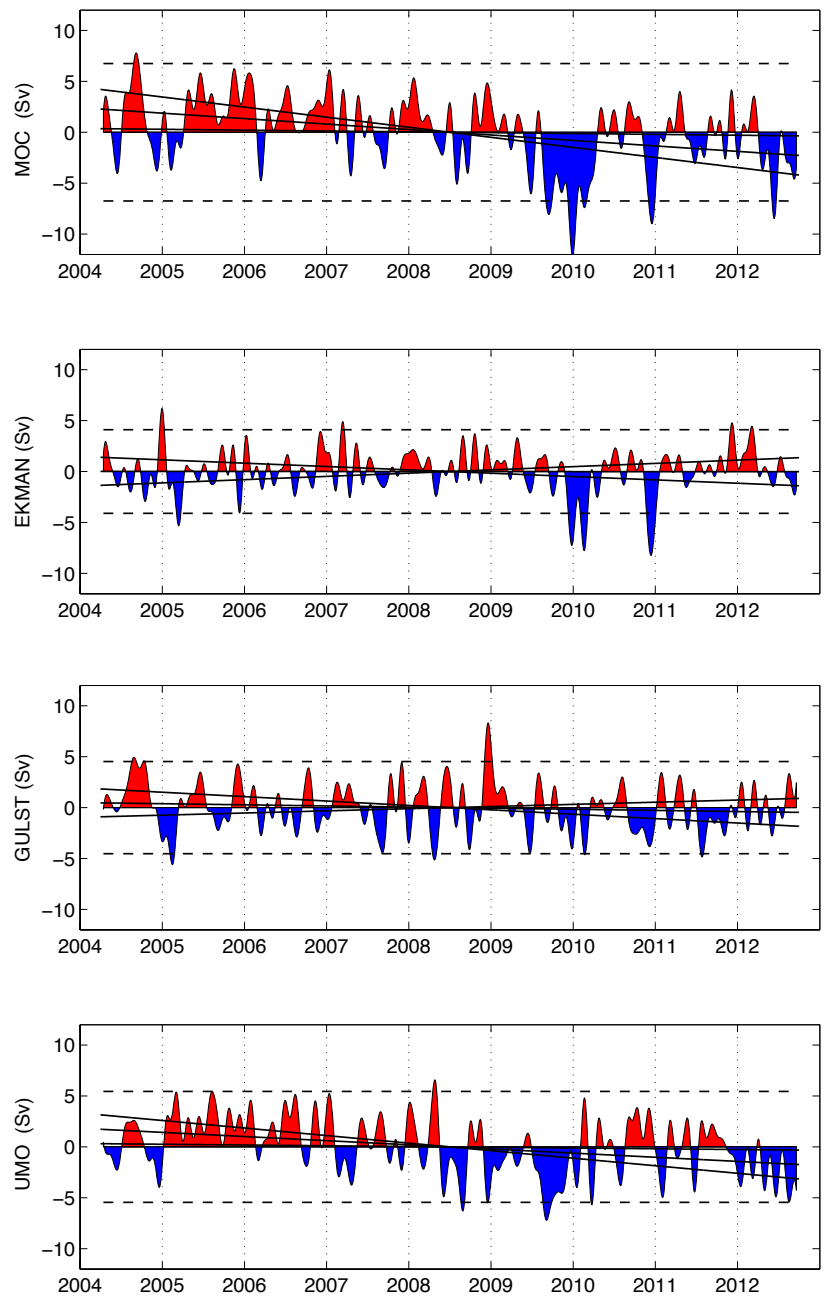

Fig. 3. Anomalies (positive is northward) relative to mean annual cycle. From top to bottom: MOC, Ekman, Gulf Stream, and UMO. A 45-day low-pass filter was applied to each time series. For each time series horizontal dashed lines show \pm 2 standard deviations and the solid black lines show the average trend \pm 1.64 standard errors (i.e. $90 \%$ confidence limits).

function of annual period and two harmonics to the ten-day filtered data. The annual cycle for the AMOC is shown in Fig. 2. The annual cycles were then subtracted from the original data to create de-seasonalized time series; filtered versions of these data are shown in Fig. 3.

Calculation of the standard error of the estimated trend requires an estimation of the number of degrees of freedom in the time series. Several approaches can be used to determine the integral timescale and degrees of freedom. Here we followed Leith (1973) and set

Degrees of freedom $=\frac{\text { Length of timeseries }}{2 \times \text { e-folding time of autocorrelation }}$.

The e-folding timescales were determined by fitting an exponential function to the 10-day filtered data after removal
Table 2. Estimated changes for the AMOC at $26^{\circ} \mathrm{N}$ and its component parts between the period from April 2004 to March 2008 and the period from April 2008 to March 2012. Two values are shown for each variable. The first (upper) value includes the year starting in April 2009 and the second excludes 2009. Also shown are the 5 and 95 percentile values of the estimate. All values are Sv. Positive implies increased northward transport (or reduced southward transport).

\begin{tabular}{lrrrr}
\hline \multirow{2}{*}{ Variable } & $\begin{array}{r}\text { Mean value } \\
\text { 2004-2012 }\end{array}$ & \multicolumn{3}{c}{ Estimated change } \\
Confidence value & & $5 \%$ & $50 \%$ & $95 \%$ \\
\hline AMOC & 17.5 & -5.1 & -2.7 & -0.3 \\
& & -3.0 & -1.6 & -0.2 \\
\hline Gulf Stream & 31.5 & -1.2 & -0.5 & 0.2 \\
& & -1.0 & -0.3 & 0.4 \\
\hline \multirow{2}{*}{ Ekman } & 3.5 & -1.3 & -0.2 & 0.9 \\
& & -0.7 & 0.2 & 1.0 \\
\hline Upper mid-ocean (UMO) & -17.5 & -3.4 & -2.0 & -0.6 \\
& & -2.7 & -1.5 & -0.2 \\
\hline UNADW & -11.6 & -0.7 & 0.1 & 0.9 \\
& & -0.8 & -0.2 & 0.4 \\
\hline LNADW & -6.5 & 0.5 & 2.1 & 3.8 \\
& & 0.2 & 1.5 & 2.7 \\
\hline
\end{tabular}

of the seasonal cycle. The values obtained were 40 days for the MOC, 24 days for the Ekman transport, 14 days for the Gulf Stream and 21 days for the UMO. Based on an $8.5 \mathrm{yr}$ record length, these e-folding scales correspond to estimates of the number of degrees of freedom between 39 and 111; to be conservative here a value of 35 degrees of freedom was used for each time series.

Superimposed on the data in Fig. 3 are the trends calculated by linear regression of the 10-day filtered data. Lines illustrating the trend \pm 1.64 standard errors (for 35 degrees of freedom) are also shown. These represent the $90 \%$ confidence interval for the trend. The estimated trend in the AMOC is $-0.54 \mathrm{~Sv} \mathrm{yr}^{-1}\left(90 \%\right.$ c.i. -0.08 to $\left.-0.99 \mathrm{~Sv} \mathrm{yr}^{-1}\right)$. This is consistent with the values obtained in the previous section by looking at the four-year mean. The results in Table 2 suggest a reduction of $2.7 \mathrm{~Sv}$ over a four-year equivalent to a trend of about $-0.68 \mathrm{~Sv} \mathrm{yr}^{-1}$. Trends and confidence intervals for the components of the AMOC are summarized in Table 3. The UMO is the only component that has a trend significantly different from zero $\left(-0.41 \mathrm{~Sv} \mathrm{yr}^{-1}, 90 \%\right.$ c.i. -0.07 to $\left.-0.74 \mathrm{~Sv} \mathrm{yr}^{-1}\right)$. The trend in the de-seasonalized time series of the AMOC accounts for $10 \%$ of the total variance of the AMOC 10-day low-pass filtered time series. After removal of the trend the standard deviation of the AMOC residuals is $4.0 \mathrm{~Sv}$.

The analysis was also applied to the time series with data from April 2009 to March 2010 removed. In this case the trend was a little weaker being $-0.42 \mathrm{~Sv} \mathrm{yr}^{-1}$ (90\% c.i. 0.01 to $-0.84 \mathrm{~Sv} \mathrm{yr}^{-1}$ based on 31 degrees of freedom). 
Table 3. Estimated trends for the AMOC at $26^{\circ} \mathrm{N}$ and its component parts. Two values are shown for each variable. The first (upper) value includes the year starting in April 2009 and the second excludes 2009. Also shown are the 5 and 95 percentile values of the

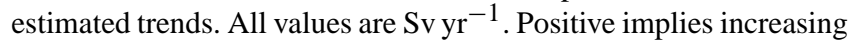
northward transport (or reducing southward transport). The number of degrees of freedom was set to 35 for the full time series and 31 when excluding data from 2009-2010.

\begin{tabular}{lrrr}
\hline Variable & \multicolumn{3}{c}{ Estimated trend } \\
\hline Confidence value & $5 \%$ & $50 \%$ & $95 \%$ \\
\hline AMOC & -0.99 & -0.54 & -0.08 \\
& -0.84 & -0.42 & 0.01 \\
\hline Gulf Stream & -0.43 & -0.11 & 0.21 \\
& -0.42 & -0.09 & 0.24 \\
\hline Ekman & -0.33 & 0.00 & 0.32 \\
& -0.27 & 0.04 & 0.36 \\
\hline Upper mid-ocean (UMO) & -0.74 & -0.41 & -0.07 \\
Upper mid-ocean (UMO) & -0.68 & -0.36 & -0.03 \\
\hline UNADW & -0.29 & -0.03 & 0.22 \\
& -0.26 & -0.00 & 0.26 \\
\hline LNADW & 0.16 & 0.46 & 0.77 \\
& 0.11 & 0.39 & 0.68 \\
\hline
\end{tabular}

A further assumption in the estimation of the regression coefficients is that the deviations about the trend are approximately normal. In fact the distribution of residuals shows a slight skewness towards negative values, and so a second calculation was made using maximum likelihood estimation to fit a linear regression model with skew-normal errors (Azzalini and Capitanio, 1999). There was however no significant change to the results.

\subsection{Transport profiles}

Comparison of the annual means in Sect. 3.1 indicated that the slowing of the AMOC was primarily due to the strengthening of the southward flowing waters above the thermocline in the basin interior. To examine this further we show in Fig. 4 the stream function profile averaged over the first four years of the time series and over the last four years. Also shown is the difference between the two and the corresponding change in the transport per depth profile. It can be seen that during the later period there was a stronger southward flow above $1000 \mathrm{~m}$ depth that intensified towards the surface. The vertical integral of the transport per depth profile must be zero and so there is a corresponding weakening of the southward flow in the deeper layers. Figure 4 indicates that this occurred below $2000 \mathrm{~m}$ and mostly below $3000 \mathrm{~m}$. There is a broad maximum in the change around $4000 \mathrm{~m}$.

Southward flow of water between $1100 \mathrm{~m}$ and $3000 \mathrm{~m}$ is usually regarded as upper North Atlantic deep water
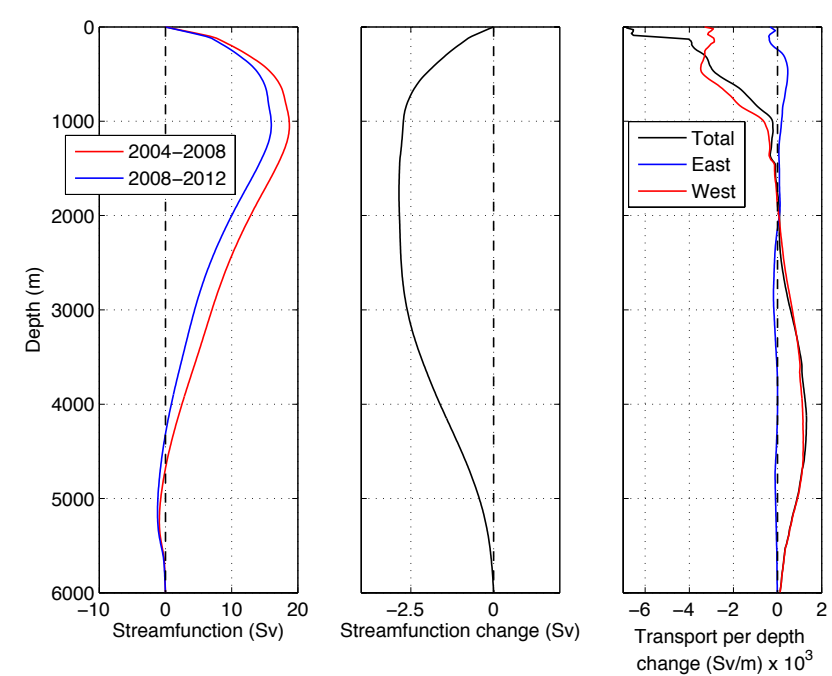

Fig. 4. Left: mean stream function profile (Sv) for the two four-year periods April 2004 to March 2008 and April 2008 to March 2012. Centre: difference between the two profiles in the left hand plot. Right: change of the transport per depth profiles $\left(\mathrm{Sv} \mathrm{m}^{-1}\right)$ between the two four-year periods, positive values correspond to northward flow. Black shows total change in transport per depth, blue shows that part due to changes on the eastern boundary and red shows that part of the change due to changes on the western boundary. Note that the black curve includes changes of Ekman and Gulf Stream transports and a small contribution form changes of density adjacent to the mid-Atlantic ridge.

(UNADW), while the flow between $3000 \mathrm{~m}$ and $5000 \mathrm{~m}$ is regarded as lower North Atlantic deep water (LNADW) (see for example Atkinson et al., 2012). In Fig. 5 we show desesonalized transport time series for each of these depth ranges. There is a significant trend of decreasing transport in LNADW but no apparent change in the transport of UNADW (Table 3). The mean value of the transport of LNADW over the eight years of the time series is $6.5 \mathrm{~Sv}$ southward. Thus as a percentage of the mean the absolute change in transport of LNADW is greater than that of the UMO and amounts to $7 \%$ per year $(95 \%$ confidence that the reduction is more than $2.5 \%$ per year). For the UMO the rate is $3 \%$ per year (95\% confidence that the increase is more than $0.5 \%$ per year).

The change to the interior geostrophic flow may be separated into two parts corresponding to the changes on the eastern and western boundaries and these are shown by the blue and red curves in the right hand panel of Fig. 4. It can be seen that the transport change is due in large part to the changes on the western boundary. The RAPID array combines data from several moorings on the sloping boundaries to create one merged profile of temperature and salinity on the west and one on the east. Further details are given in the supplementary material of Cunningham et al. (2007). The changes in density on the eastern and western merged profiles are shown in Fig. 6. The left hand panel of Fig. 6 shows 

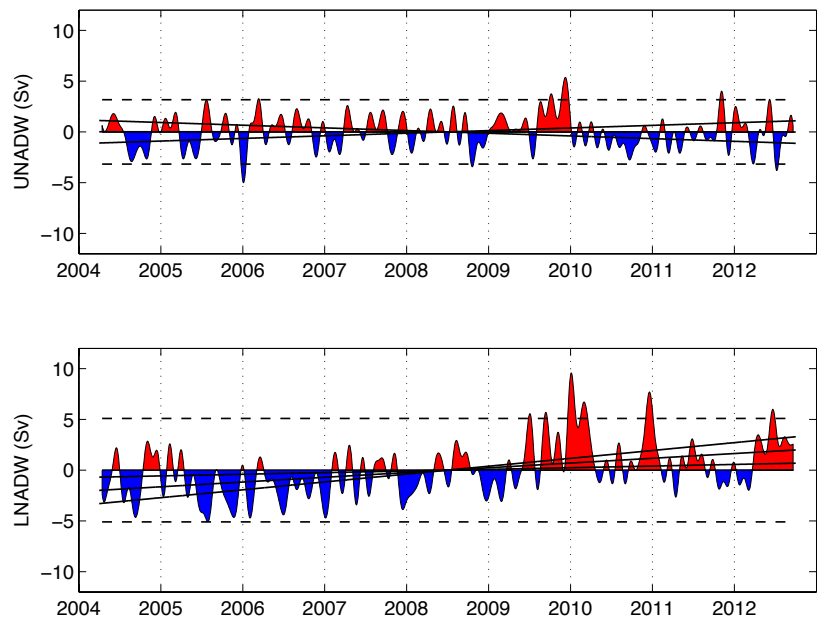

Fig. 5. Time series of the upper NADW (top) and lower NADW (bottom). Values are anomalies relative to mean annual cycle (positive is northward). A 45-day low-pass filter was applied to each time series. For each time series horizontal dashed lines show \pm two standard deviations and the solid black lines show the average trend \pm 1.64 standard errors (i.e. $90 \%$ confidence limits).

the difference between the profiles averaged over the period from 2008 to 2012 and those averaged the period from 2004 to 2008. Except in the upper $500 \mathrm{~m}$ the changes on the west are greater than those on the east and so we focus our attention on the western profile. Temperature and salinity both increase towards the surface (Fig. 6, right hand panel) and so vertical displacement of isopycnals results in temperature and salinity having opposing effects on density at fixed depth levels with temperature having the greatest effect. Figure 6 shows that the main changes are a reduction in density at depths of $500 \mathrm{~m}$ to $1200 \mathrm{~m}$. There is also an increase in density above $500 \mathrm{~m}$ due to a cooling of the upper layers (also evident on the east). However, this had less impact on the change in transport. On deeper layers there was a reduction of density between $2000 \mathrm{~m}$ and $4000 \mathrm{~m}$. Comparing the changes due to temperature and salinity indicates that isopycnals have deepened in this depth range too, but there has also been a freshening and cooling on isopycnal surfaces.

\section{Discussion}

\subsection{Relationship of AMOC changes to the climate of the North Atlantic}

Excluding the anomalous year of 2009, the mean AMOC for the second half of the $26^{\circ} \mathrm{N}$ measurements (2008-2012) is about $1.6 \mathrm{~Sv}(90 \%$ c.i. 0.2 to $3.0 \mathrm{~Sv}$ ) lower than the first four years. Including 2009 increases the reduction to $2.7 \mathrm{~Sv}(90 \%$ c.i. 0.3 to $5.1 \mathrm{~Sv}$ ). Model simulations predict a decrease of the AMOC in the 21st century in response to increasing
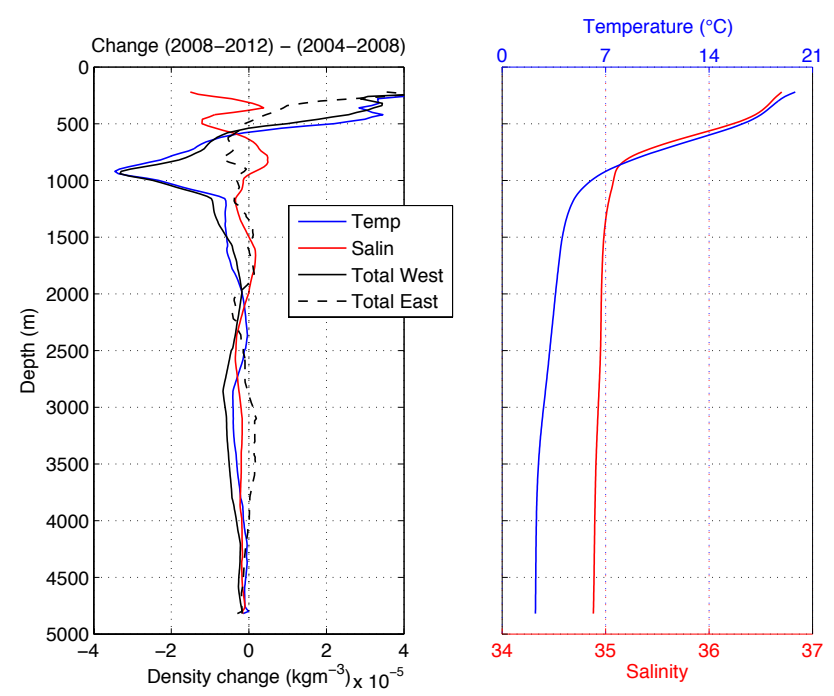

Fig. 6. Left: mean density difference (black) between the two four-year periods: April 2004 to March 2008 and April 2008 to March 2012. Continuous line shows the change on the western boundary and dashed shows the change on the eastern boundary. Also shown is that part of the density change on the western boundary due to temperature (blue) and that due to salinity (red). Left: mean temperature (blue) and salinity (red) profiles on the western boundary of the $26^{\circ} \mathrm{N}$ array.

greenhouse gases of the order of one half a Sverdrup per decade (IPCC, 2007). Our observations indicate that the actual change over the last decade is much greater. The magnitude of the observed changes suggests that they are a part of a cyclical change rather than being directly linked to the projected anthropogenic AMOC decrease. A much longer time series would be needed to identify a trend of the magnitude associated with greenhouse warming in model simulations. Thomas et al. (2012) looked at how the components of the AMOC changed during a warming scenario in a model simulation and found that the reduction of the AMOC was primarily a reduction in southward flow of deep water balanced by a reduced Gulf Stream with little change in the strength of the gyre circulation, which appeared to be determined by Sverdrup balance. This contrasts with our observations that show no significant change in the Gulf Stream transport over the 2004-2012 period when the AMOC is decreasing.

The majority of the change in the AMOC is associated with the UMO transport, which was about $1.5 \mathrm{~Sv}(90 \%$ c.i. -0.1 to $3.0 \mathrm{~Sv}$ ) lower in the latter four years than in the first four years. Including 2009 increases the reduction to $2.0 \mathrm{~Sv}$ (90\% c.i. 0.2 to $3.7 \mathrm{~Sv}$ ). Model simulations completed by Matei et al. (2012) exhibited some skill in hindcasting the AMOC at $26^{\circ} \mathrm{N}$, and they concluded that this skill was associated primarily with the interior mid-ocean transport and the long timescales associated with internal ocean dynamics. 


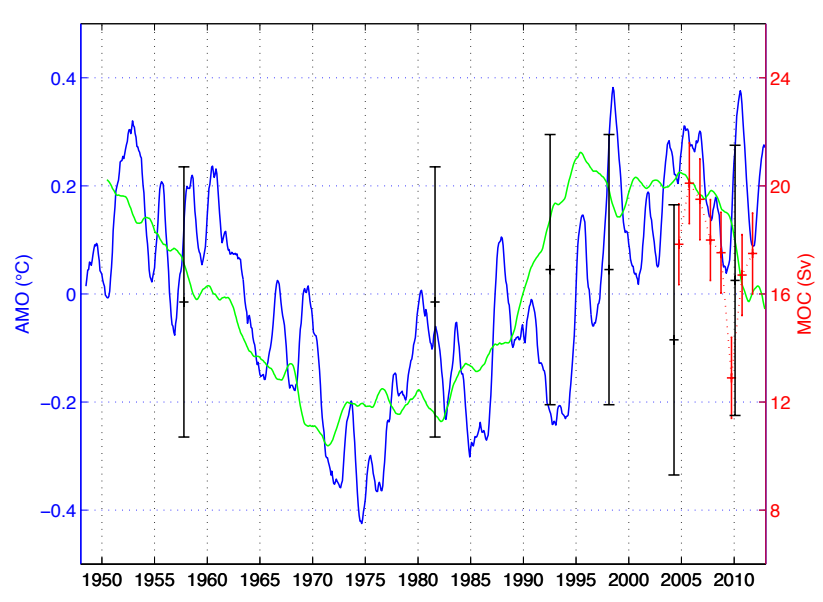

Fig. 7. Annual average estimates of the AMOC from the $26^{\circ} \mathrm{N}$ array (red, $\mathrm{Sv}$ right axis, error bar $=1.5 \mathrm{~Sv}$ ), estimates of the AMOC from 6 hydrographic sections (black, Sv right axis, error bar $=5 \mathrm{~Sv}$ ), the time series of annual average values of the AMO (blue, ${ }^{\circ} \mathrm{C}$ left axis) and accumulated NAO index (green, arbitrary units).

During the time of the $26^{\circ} \mathrm{N}$ array observations there has been a predominantly negative NAO (Fig. 7). Associated with the negative NAO is a tripole SST pattern with cooler mid-latitudes and warm subtropics. Cunningham et al. (2013) suggested that the AMOC has a role in setting sub-surface temperature anomalies, which have been linked to re-emerging SST patterns and subsequent anomalies in the NAO (Taws et al., 2011). The results presented here are consistent with AMOC driven changes to the SST tripole pattern but they are not sufficient to conclude a causal relationship. $\mathrm{Li}$ et al. (2012) found an anti-correlation between sea-surface height (SSH) between $30^{\circ}$ and $50^{\circ} \mathrm{N}$ in the Atlantic and accumulated (i.e. time integrated) NAO. If SSH changes primarily reflect variations in heat content then this also supports the association of reducing AMOC and negative NAO.

In Fig. 7 we show the data from the $26^{\circ} \mathrm{N}$ observations superimposed on the accumulated NAO and the index for the Atlantic multidecadal oscillation (AMO). To date the length of the $26^{\circ} \mathrm{N}$ time series is short compared with timescale of the low frequency variability of the AMO (of the order of $60 \mathrm{yr}$ ). However, snapshots of the AMOC were made in hydrographic cruises going back to 1957 and these are also shown on Fig. 7. The values are taken from Table 5 in (Atkinson et al., 2012), which compared all six section from 1957, 1981, 1992, 1998, 2004 and 2010 and adjusted the figures to remove the effect of the seasonal variability as determined from the $26^{\circ} \mathrm{N}$ observations. However, we used annual average values for the Ekman and Gulf Stream components. The error bars on the hydrographic estimates are too large to draw any conclusions about the association of the AMOC with the NAO or AMO. Bryden et al. (2005) suggested that the errors could be as large as $6 \mathrm{~Sv}$. In fact the AMOC measured by the hydrographic cruise in 2010 was stronger than that in
2004. This underlines the fact that continuous observations are required to determine the variability of the AMOC.

\subsection{Deep water changes}

The results presented here indicate that the reduction of the AMOC between April 2004 and October 2012 was manifested as a strengthening of the southward flow of the waters above the thermocline and a weakening of the southward flow of lower North Atlantic deep water (LNADW). Surprisingly the upper North Atlantic deep water (UNADW) has shown little change.

Send et al. (2011) reported observations from the MOVE array at $16^{\circ} \mathrm{N}$. The MOVE array (Kanzow et al., 2006) measures the deep flow on the western side of the Atlantic only but Send et al. (2011) argued that this captures all of the southward deep water flow. Send et al. (2011) concluded that there was a reduction of about $3 \mathrm{~Sv}$ in the southward flow of NADW between 2000 and 2009. In contrast to our observations Send et al. (2011) attributed most of the changes to the variability of UNADW and found that LNADW transport remained roughly constant. Whilst there is an overlap of about $5 \mathrm{yr}$ (2004-2009) between the period considered by Send et al. (2011) and our record, it is not sufficient to make a direct comparison with the data reported in this paper, where the major change was observed after 2008. Furthermore, the advection time from the $26^{\circ} \mathrm{N}$ array to the MOVE array is expected to be about $2-3 \mathrm{yr}$, assuming the speed of advection between $26^{\circ} \mathrm{N}$ and $15^{\circ} \mathrm{N}$ is similar to that between the Labrador Sea and $26^{\circ} \mathrm{N}$ which was found to be about $9 \mathrm{yr}$ by van Sebille et al. (2011) though faster wave mediated responses are also expected (Johnson and Marshall, 2002).

Mercier et al. (2013) have used repeat hydrographic sections, Argo data and altimetry to diagnose the AMOC in the sub-polar gyre. They found a reduction in overturning between 1993 and 2010 of about 2.4 Sv. However, a significantly longer period of overlap between the time series at $26^{\circ} \mathrm{N}$ and the Greenland-Portugal section would be needed to asses the meridional coherence of variability in the AMOC.

A primary driver of the thermohaline circulation is the formation of deep waters at high latitudes. Observations of the deep water formation regions and the overflows suggest that the rate of formation in the Nordic Seas has remained remarkably constant (Jochumsen et al., 2012; Olsen et al., 2008), whereas variability of deep-water formation in the Labrador and Irminger seas has been documented (e.g. Yashayaev and Loder, 2009). Climate models also generally indicate that changes in the AMOC strength are linked to changes in convection in the Labrador and Irminger seas (Danabasoglu et al., 2012). This would lead us to expect greater variability in the UNADW than in the LNADW. Changes in temperature and salinity on the western boundary of the $26^{\circ} \mathrm{N}$ array (Fig. 4) do indicate freshening and warming of UNADW and this is consistent with the changes 
described by Peña-Molino et al. (2011) and van Sebille et al. (2011), but no significant change in the transport of UNADW is apparent. It is also interesting to note that in the modelling study of the period from 1985 to 2002 by Marsh et al. (2005), variability in the formation of UNADW in the Labrador Sea was not seen to affect the MOC at $26^{\circ} \mathrm{N}$.

Our observations alone cannot explain the changes in the deep water circulation, but reconciling our observations at $26^{\circ} \mathrm{N}$ with a constant production of LNADW requires a time-varying meridional divergence and convergence associated with a decadal change in the circulation. On average there was $2 \mathrm{~Sv}$ less southward transport of LNADW at $26^{\circ} \mathrm{N}$ from 2008 to 2012 than there was from 2004 to 2008. If the volume transport of the overflows has remained constant this would imply an average change in the rate of convergence equivalent to an uplift of about $5 \mathrm{~m} \mathrm{yr}^{-1}$ over the $1.34 \times 10^{7} \mathrm{~km}^{2}$ of the North Atlantic between $26^{\circ} \mathrm{N}$ and $60^{\circ} \mathrm{N}$ that is deeper than $3000 \mathrm{~m}$. Without further information we can only infer the change but not the absolute value of the uplift. Cunningham and Alderson (2007), based on an analysis of deep isopycnal displacements near the western boundary at $26.5^{\circ} \mathrm{N}$, conclude that there was about $50 \mathrm{~m}$ of uplift of the upper interface of LNADW between 1957 an 2004.

\section{Conclusions}

On the timescale of decadal changes in the North Atlantic the $8.5 \mathrm{yr}$ length of the $26^{\circ} \mathrm{N}$ array observations is still short, but the results demonstrate the capability of the array to detect changes in the magnitude and structure of the overturning circulation. We have shown that there was a slowdown in the AMOC transport between 2004 and 2012 amounting to an average of $-0.54 \mathrm{~Sv} \mathrm{yr}^{-1}\left(95 \%\right.$ c.i. -0.08 to $\left.-0.99 \mathrm{~Sv} \mathrm{yr}^{-1}\right)$ at $26^{\circ} \mathrm{N}$, and that this was primarily due to a strengthening of the southward flow in the upper $1100 \mathrm{~m}$ and a reduction of the southward transport of NADW below $3000 \mathrm{~m}$. This trend is an order of magnitude larger than that predicted by climate models associated with global climate change scenarios, suggesting that this decrease represents decadal variability in the AMOC system rather than a response to climate change. Further observations from the $26^{\circ} \mathrm{N}$ array will in time allow a better understanding of decadal variability of the AMOC and its relationship to the climate of the North Atlantic region.

Acknowledgements. The $26^{\circ} \mathrm{N}$ array is a collaborative effort supported through the UK Natural Environment Research Council (NERC) RAPID-WATCH program, the US National Science Foundation (NSF) Meridional Overturning Circulation Heatflux Array project, and the US National Oceanographic and Atmospheric Administration (NOAA) Western Boundary Time Series project. Data from the RAPID-WATCH \& MOCHA projects are freely available from www.rapid.ac.uk/rapidmoc and www.rsmas.miami.edu/users/mocha. Florida Current transports estimates are available from www.aoml.noaa.gov/phod/floridacurrent. Additional support is received from the European Commission in the 7th Framework Programme for Research through the NACLIM project (Grant Agreement 308299). Stuart Cunningham is supported by the Scottish Funding Council (Grant Reference HR09011) through the Marine Alliance for Science and Technology Scotland programme. Special thanks to the officers, crew, technical and science parties involved in the hydrographic data collection and mooring deployment and recovery operations. Data for the NAO and AMO indices were downloaded from http://stateoftheocean.osmc.noaa.gov.

Edited by: A. Schiller

\section{References}

Atkinson, C. P., Bryden, H. L., Cunningham, S. A., and King, B. A.: Atlantic transport variability at $25^{\circ} \mathrm{N}$ in six hydrographic sections, Ocean Sci., 8, 497-523, doi:10.5194/os-8-497-2012, 2012.

Azzalini, A. and Capitanio, A.: Statistical applications of the multivariate skew normal distribution, J. Roy. Stat. Soc. B, 61, 579602, doi:10.1111/1467-9868.00194, 1999.

Baringer, M. O. and Larsen, J. C.: Sixteen years of Florida Current transport at $27^{\circ} \mathrm{N}$, Geophys. Res. Lett., 28, 3179-3182, 2001.

Bryden, H. and Hall, M.: Heat transports by currents across $25^{\circ} \mathrm{N}$ latitude in the Atlantic Ocean, Science, 207, 884-885, 1980.

Bryden, H. L., Longworth, H. R., and Cunningham, S. A.: Slowing of the Atlantic meridional overturning circulation at $25^{\circ} \mathrm{N}$, Nature, 438, 655-657, doi:10.1038/nature04385, 2005.

Cunningham, S. A. and Alderson, S. G.: Transatlantic temperature and salinity changes at $24.5^{\circ} \mathrm{N}$ from 1957 to 2004, Geophys. Res. Lett., 34 L14606, doi:10.1029/2007GL029821, 2007.

Cunningham, S. A., Kanzow, T., Rayner, D., Baringer, M. O., Johns, W. E., Marotzke, J., Longworth, H. R., Grant, E. M., Hirschi, J. J.-M., Beal, L. M., Meinen, C. S., and Bryden, H. L.: Temporal variability of the Atlantic Meridional Overturning Circulation at 26.5 N, Science, 317, 935-938, doi:10.1126/science.1141304, 2007.

Cunningham, S. A., Roberts, C. D., Frajka-Williams, E., Johns, W. E., Hobbs, W., Palmer, M. D., Rayner, D., Smeed, D. A., and McCarthy, G.: Atlantic Meridional Overturning Circulation slowdown cooled the subtropical ocean, Geophys. Res. Lett., online first, doi:10.1002/2013GL058464, 2013.

Danabasoglu, G., Yeager, S. G., Kwon, Y.-O., Tribbia, J. J., Phillips, A. S., and Hurrell, J. W.: Variability of the Atlantic Meridional Overturning Circulation in CCSM4, J. Climate, 25, 5153-5172, doi:10.1175/JCLI-D-11-00463.1, 2012.

Dee, D. P., Uppala, S. M., Simmons, A. J., Berrisford, P., Poli, P., Kobayashi, S., Andrae, U., Balmaseda, M. A., Balsamo, G., Bauer, P., Bechtold, P., Beljaars, A. C. M., van de Berg, L., Bidlot, J., Bormann, N., Delsol, C., Dragani, R., Fuentes, M., Geer, A. J., Haimberger, L., Healy, S. B., Hersbach, H., Hólm, E. V., Isaksen, L., Kållberg, P., Köhler, M., Matricardi, M., McNally, A. P., Monge-Sanz, B. M., Morcrette, J. J., Park, B. K., Peubey, C., de Rosnay, P., Tavolato, C., Thépaut, J. N., and Vitart, F.: The ERA-Interim reanalysis: configuration and performance of the 
data assimilation system, Q. J. Roy. Meteorol. Soc., 137, 553597, doi:10.1002/qj.828, 2011.

Delworth, T. L. and Mann, M. E.: Observed and simulated multidecadal variability in the Northern Hemisphere, Clim. Dynam., 16, 661-676, 2000.

Eden, C. and Willebrand, J.: Mechanism of interannual to decadal variability of the North Atlantic circulation, J. Climate, 14, 22662280, 2001.

Ganopolski, A. and Rahmstorf, S.: Rapid changes of glacial climate simulated in a coupled climate model, Nature, 409, 153158, doi:10.1038/35051500, 2001.

IPCC: Climate Change 2007: The Physical Science Basis, edited by: Solomon, S., Qin, D., Manning, M., Chen, Z., Marquis, M., Averyt, K. B., Tignor, M., and Miller, H. L., Cambridge University Press, 2007.

Jochumsen, K., Quadfasel, D., Valdimarsson, H., and Jónsson, S.: Variability of the Denmark Strait overflow: Moored time series from 1996-2011, J. Geophys. Res.-Oceans, 117, C12003, doi:10.1029/2012JC008244, 2012.

Johns, W. E., Beal, L. M., Baringer, M. O., Molina, J., Rayner, D., Cunningham, S. A., and Kanzow, T. O.: Variability of shallow and deep western boundary currents off the Bahamas during 2004-2005: First results from the $26^{\circ} \mathrm{N}$ RAPID-MOC array, J. Phys. Oceanogr., 38, 605-623, 2008.

Johns, W. E., Baringer, M. O., Beal, L. M., Cunningham, S. A., Kanzow, T., Bryden, H. L., Hirschi, J. J.-M., Marotzke, J., Meinen, C. S., Shaw, B., and Curry, R.: Continuous, array-based estimates of Atlantic Ocean heat transport at $26.5^{\circ} \mathrm{N}$, J. Climate, 24, 24292449, doi:10.1175/2010JCLI3997.1, 2011.

Johnson, H. L. and Marshall, D. P.: A Theory for the Surface Atlantic Response to Thermohaline Variability, J. Phys. Oceanogr., 32, 1121-1132, doi:10.1175/15200485(2002)032<1121:ATFTSA>2.0.CO;2, 2002.

Kanzow, T., Send, U., Zenk, W., Chave, A. and Rhein, M.: Monitoring the deep integrated meridional flow in the tropical North Atlaantic: Long-term performance of a geostrophic array, Deep Sea Res.-Pt. I, 53, 528-546, 2006.

Kanzow, T., Cunningham, S. A., Rayner, D., Hirschi, J. J.-M., Johns, W. E., Baringer, M. O., Bryden, H. L., Beal, L. M., Meinen, C. S., and Marotzke, J.: Observed flow compensation associated with the MOC at $26.5^{\circ} \mathrm{N}$ in the Atlantic, Science, 317 , 938-941, doi:10.1126/science.1141293, 2007.

Kanzow, T., Cunningham, S. A., Johns, W. E., Hirschi, J. J.M., Marotzke, J., Baringer, M. O., Meinen, C. S., Chidichimo, M. P., Atkinson, C., Beal, L. M., Bryden, H. L., and Collins, J.: Seasonal Variability of the Atlantic Meridional Overturning Circulation at $26.5^{\circ} \mathrm{N}$, J. Climate, 23, 5678-5698, doi:10.1175/2010JCLI3389.1, 2010.

Knight, J. R., Allan, R. J., Folland, C. K., Vellinga, M., and Mann, M. E.: A signature of persistent natural thermohaline circulation cycles in observed climate, Geophys. Res. Lett., 32, L20708, doi:10.1029/2005GL024233, 2005.

Leith, C. E.: The Standard Error of Time-Average Estimates of Climatic Means, J. Appl. Meteorol., 12, 1066-1069, doi:10.1175/1520-0450(1973)012<1066:TSEOTA>2.0.CO;2, 1973.

Li, F., Jo, Y.-H., Liu, W. T., and Yan, X.-H.: A dipole pattern of the sea surface height anomaly in the North Atlantic: 1990s-2000s,
Geophys. Res. Lett., 39, L15604, doi:10.1029/2012GL052556, 2012.

Lindgren, B. W.: Statistical Theory, 4th Edn., Chapman \& Hall/CRC, 1993.

Maidens, A., Arribas, A., Scaife, A. A., MacLachlan, C., and Peterson, D.: The Influence of Surface Forcings on Prediction of the North Atlantic Oscillation Regime of Winter 2010-11, Mon. Weather Rev., 141, 3801-3813, doi:10.1175/MWR-D-1300033.1, 2013.

Marsh, R., De Cuevas, B. A., Coward, A. C., Bryden, H. L., and Álvarez, M.: Thermohaline circulation at three key sections in the North Atlantic over 1985-2002, Geophys. Res. Lett., 32, L10604, doi:10.1029/2004GL022281, 2005.

Matei, D., Baehr, J., Jungclaus, J. H., Haak, H., Müller, W. A., and Marotzke, J.: Multiyear prediction of monthly mean Atlantic meridional overturning circulation at $26.5^{\circ} \mathrm{N}$, Science, 335, 7679, doi:10.1126/science.1210299, 2012.

McCarthy, G., Frajka-Williams, E., Johns, W. E., Baringer, M. O., Meinen, C. S., Bryden, H. L., Rayner, D., Duchez, A., Roberts, C., and Cunningham, S. A.: Observed interannual variability of the Atlantic meridional overturning circulation at $26.5^{\circ} \mathrm{N}$, Geophys. Res. Lett., 39, L19609, doi:10.1029/2012GL052933, 2012.

Meinen, C. S., Garzoli, S. L., Johns, W. E., and Baringer, M. O.: Transport variability of the Deep Western Boundary Current and the Antilles Current off Abaco Island, Bahamas, Deep Sea Res.Pt. I, 51, 1397-1415, doi:10.1016/j.dsr.2004.07.007, 2004.

Meinen, C. S., Baringer, M. O., and Garcia, R. F.: Florida Current transport variability: An analysis of annual and longer-period signals, Deep Sea Res.-Pt. I, 57, 835-846, doi:10.1016/j.dsr.2010.04.001, 2010.

Mercier, H., Lherminier, P., Sarafanov, A., Gaillard, F., Daniault, N., Desbruyères, D., Falina, A., Ferron, B., Gourcuff, C., Huck, T., and Thierry, V.: Variability of the meridional overturning circulation at the Greenland-Portugal OVIDE section from 1993 to 2010, Prog. Oceanogr., doi:10.1016/j.pocean.2013.11.001, 2013.

Olsen, S. M., Hansen, B., Quadfasel, D., and Østerhus, S.: Observed and modelled stability of overflow across the GreenlandScotland ridge, Nature, 455, 519-522, doi:10.1038/nature07302, 2008.

Peña-Molino, B., Joyce, T. M., and Toole, J. M.: Recent changes in the Labrador Sea Water within the Deep Western Boundary Current southeast of Cape Cod, Deep Sea Res.-Pt. I, 58, 10191030, doi:10.1016/j.dsr.2011.07.006, 2011.

Roemmich, D. and Wunsch, C.: Two transatlantic sections: meridional circulation and heat flux in the subtropical North Atlantic Ocean, Deep Sea Res.-Pt. I, 32, 619-664, doi:10.1016/01980149(85)90070-6, 1985.

Send, U., Lankhorst, M., and Kanzow, T.: Observation of decadal change in the Atlantic meridional overturning circulation using 10 years of continuous transport data, Geophys. Res. Lett., 38, L24606, doi:10.1029/2011GL049801, 2011.

Srokoz, M. A., Baringer, M., Bryden, H., Cunningham, A. A., Delworth, T., Lozier, S., Marotzke, J., and Suttion, R.: Past, present and future change in the Atlantic meridional overturning circulation, B. Am. Meteorol. Soc., 93, 1663-1676, doi:10.1175/BAMS-D-11-00151.1, 2012.

Taws, S. L., Marsh, R., Wells, N. C., and Hirschi, J.: Reemerging ocean temperature anomalies in late-2010 associated 
with a repeat negative NAO, Geophys. Res. Lett., 38, L20601, doi:10.1029/2011GL048978, 2011.

Thomas, M. D., de Boer, A. M., Stevens, D. P., and Johnson, H. L.: Upper ocean manifestations of a reducing meridional overturning circulation, Geophys. Res. Lett., 39, L16609, doi:10.1029/2012GL052702, 2012.

van Sebille, E., Baringer, M. O., Johns, W. E., Meinen, C. S., Beal, L. M., de Jong, M. F., and van Aken, H. M.: Propagation pathways of classical Labrador Sea water from its source region to $26^{\circ} \mathrm{N}$, J. Geophys. Res.-Oceans, 116, C12027, doi:10.1029/2011JC007171, 2011.
Yashayaev, I. and Loder, J. W.: Enhanced production of Labrador Sea Water in 2008, Geophys. Res. Lett., 36, L01606, doi:10.1029/2008GL036162, 2009. 